\title{
Association between In Utero arsenic exposure, placental gene expression, and infant birth weight: a US birth cohort study
}

Dennis Liang Fei ${ }^{1,2,7 \dagger}$, Devin C Koestler ${ }^{3 \dagger}$, Zhigang Li ${ }^{3}$, Camilla Giambelli ${ }^{1}$, Avencia Sanchez-Mejias ${ }^{1}$, Julie A Gosse ${ }^{4}$, Carmen J Marsit $^{3}$, Margaret R Karagas ${ }^{3^{*}}$ and David J Robbins ${ }^{1,5,6^{*}}$

\begin{abstract}
Background: Epidemiologic studies and animal models suggest that in utero arsenic exposure affects fetal health, with a negative association between maternal arsenic ingestion and infant birth weight often observed. However, the molecular mechanisms for this association remain elusive. In the present study, we aimed to increase our understanding of the impact of low-dose arsenic exposure on fetal health by identifying possible arsenic-associated fetal tissue biomarkers in a cohort of pregnant women exposed to arsenic at low levels.

Methods: Arsenic concentrations were determined from the urine samples of a cohort of 133 pregnant women from New Hampshire. Placental tissue samples collected from enrollees were homogenized and profiled for gene expression across a panel of candidate genes, including known arsenic regulated targets and genes involved in arsenic transport, metabolism, or disease susceptibility. Multivariable adjusted linear regression models were used to examine the relationship of candidate gene expression with arsenic exposure or with birth weight of the baby.

Results: Placental expression of the arsenic transporter AQP9 was positively associated with maternal urinary arsenic levels during pregnancy (coefficient estimate: $0.25 ; 95 \%$ confidence interval: $0.05-0.45$ ). Placental expression of AQP9 related to expression of the phospholipase ENPP2 which was positively associated with infant birth weight (coefficient estimate: $0.28 ; 95 \% \mathrm{Cl}: 0.09-0.47$ ). A structural equation model indicated that these genes may mediate arsenic's effect on infant birth weight (coefficient estimate: $-0.009 ; 95 \%$ confidence interval: $-0.032--0.001 ; 10,000$ replications for bootstrapping).

Conclusions: We identified the expression of AQP9 as a potential fetal biomarker for arsenic exposure. Further, we identified a positive association between the placental expression of phospholipase ENPP2 and infant birth weight. These findings suggest a path by which arsenic may affect birth outcomes.
\end{abstract}

Keywords: Arsenic, AQP9, ENPP2, Birth weight, Placenta, Biomarker

\section{Background}

The environmental toxicant arsenic poses a significant threat to adult human health [1,2]. Emerging evidence now suggests that arsenic exposure in utero also poses health risks to the developing fetus [1-3]. A number of

\footnotetext{
*Correspondence: margaret.karagas@dartmouth.edu; drobbins@med.miami. edu

${ }^{\dagger}$ Equal contributors

${ }^{3}$ Department of Community and Family Medicine, Geisel School of Medicine at Dartmouth, Hanover, NH 03755, USA

'Department of Surgery, Molecular Oncology Program, Miller School of

Medicine, University of Miami, Miami, FL 33136, USA

Full list of author information is available at the end of the article
}

epidemiological studies have found significant associations between prenatal arsenic exposure and adverse infant outcomes, such as infant mortality, low birth weight, and birth defects [4-8]. These health problems were most evident in individuals exposed to high-level arsenic [2]. Conclusions from these epidemiological studies are further supported by results from animal models $[9,10]$. Moreover, an inverse association between arsenic exposure and birth weight was found in individuals with lower exposure levels $[11,12]$. Despite the strong association between arsenic exposure and a range of child 
health concerns, the mechanisms by which arsenic elicits these effects remain elusive [3,13-16].

We recently reported that food sources, such as rice, also can contribute in exposing pregnant women to arsenic [17]. This finding, coupled with elevated arsenic levels detected in infant food [18-20], has raised serious public health and scientific concerns regarding the potential for relatively common fetal/early childhood exposure to arsenic. Validated human biomarkers will facilitate risk assessment for low-level arsenic exposure during fetal development $[21,22]$. In this study, we sought to develop such biomarkers, identifying relevant genes associated with low-dose arsenic exposure in an area of United States (New Hampshire) where a cohort of pregnant women used private wells with arsenic both above and below the current drinking water maximum contaminant level (MCL) of $10 \mu \mathrm{g} / \mathrm{L}$ [2]. We also subsequently associated the expression of these biomarkers to infant birth weight to provide insight into the mechanisms underlying the adverse effect of in utero arsenic exposure on infant health.

\section{Methods}

\section{Ethics statement}

All research involving human participants has been approved by The Committee for the Protection of Human Subjects (CPHS) - the Institutional Review Board at Dartmouth College (CPHS\#20844). An informational brochure was provided to women around the time of their first prenatal visit. They were invited to participate in the study when their glucose challenge test was being requested (at around 24 to 28 weeks gestation). Written informed consent was given. All potential participants who declined to participate were not disadvantaged in any way by not participating in the study.

\section{Study cohort and arsenic measurement}

The current study consisted of 133 pregnant women from New Hampshire, and was part of the ongoing New Hampshire Birth Cohort Study evaluating the impact of environmental factors on pregnancy and child health [17]. Demographic and lifestyle information was collected during prenatal visits. Spot urine samples were collected at approximately 24-28 weeks of gestation. Details of sample collection and arsenic measurement were described previously [17]. Briefly, urine samples were analyzed for arsenic species $\left(\mathrm{As}^{\mathrm{III}}, \mathrm{As}^{\mathrm{V}}, \mathrm{DMA}^{\mathrm{V}}\right.$, $\mathrm{MMA}^{\mathrm{V}}$, and arsenobetaine) using a high-performance liquid chromatography (HPLC) ICP-MS system at the University of Arizona. The detection limit ranged from $0.1 \mu \mathrm{g} / \mathrm{L}$ to $0.15 \mu \mathrm{g} / \mathrm{L}$ for each individual arsenic species. Total urinary arsenic (U-As) was calculated by summing the concentrations of $\mathrm{As}^{\mathrm{III}}, \mathrm{As}^{\mathrm{V}}, \mathrm{DMA}^{\mathrm{V}}$ and $\mathrm{MMA}^{\mathrm{V}}$. Infant clinical characteristics, including birth weight, were recorded from the newborn's medical record.

\section{Placenta biopsy preparation and processing}

Placenta biopsies were obtained from study participants at the time of delivery by obstetrical staff. The placenta was placed on a sterile cutting surface with the umbilical cord exposed. To minimize heterogeneity by collection site, biopsies were taken at the base of the umbilical cord insertion, measuring roughly $1 \mathrm{~cm}$ deep and $1-2 \mathrm{~cm}$ across, and were placed immediately in RNAlater (Life Technologies). Care was taken to avoid maternal decidua as well as fibrous connective tissue and calcifications during sampling of the placenta parenchyma. Samples were refrigerated within 2 hours of collection and placed in a -80 degree freezer for long-term storage.

\section{RNA extraction and gene profiling using Nanostring}

RNA extraction and subsequent gene profiling were performed using three similarly sized batches (44 or 45 samples per batch). A representative piece of each placenta sample $(\sim 200 \mathrm{mg}$ wet weight) was homogenized in Tri Reagent (Molecular Research Center) using an electronic homogenizer. RNA extraction was performed following the manufacturer's directions and further purified using RNeasy columns (Qiagen). RNA quality was assessed using an Agilent Bioanalyzer. 100 ng RNA from each sample was subject to gene expression analysis using the Nanostring system (Nanostring Technologies) at the Oncogenomics Core Facility of the University of Miami [23]. The Nanostring codeset was custom designed for 9 arsenic-related genes (AKR1C3, ENPP2, HMOX1, LEP, NFE2L2, TYMS, AQP9, AS3MT, and SLC39A2. Details in Table 1) and 5 house-keeping genes (ATCB, GAPDH, HPRT1, RPL19, and RPLPO). Raw data for the expression of each gene was compiled and normalized to the spike-in positive and negative controls using the nSolver software (Nanostring Technologies). The expression of arsenicrelated genes was further normalized to the geometric mean of the expression of 5 house-keeping genes and presented as normalized counts per gene per sample.

\section{Statistical analysis}

The gene expression data from all 3 batches were first investigated for batch-to-batch variations using a principle components analysis. Batch effects were then adjusted by the COMBAT method [30]. Briefly, location (mean) and scale (variance) was adjusted using an empirical Bayes framework. Using the batch-adjusted data, a series of multivariable linear regression models were used to examine the association between U-As and gene expression for each of the candidate genes. Multivariable linear regression models modeled natural log-transformed gene expression as a function of log10-transformed U-As, and were adjusted for maternal age at delivery. Similar models were fit to investigate the association between $A Q P 9$ expression and the expression of the other candidate genes 
Table 1 Candidate genes that were examined for their associations with in utero arsenic exposure

\begin{tabular}{llll}
\hline Gene Symbol & RefSeq & Gene Name & Regulation by arsenic (biological system) [Reference] \\
\hline AKR1C3 & NM_003739 & aldo-keto reductase family 1, member C3 & Up-regulation (cell line) [24] \\
ENPP2 & NM_001040092 & autotaxin & Up-regulation (cell line) [25] \\
HMOX1 & NM_002133 & heme oxygenase 1 & Up-regulation (cell line) [26] \\
LEP & NM_000230 & leptin & Up-regulation (placenta) [14] \\
NFE2L2 & NM_001145413 & nuclear factor (erythroid-derived 2)-like 2 & Up-regulation (cell line) [27] \\
TYMS & NM_001071 & thymidylate synthetase & Down-regulation (cell line, primary white blood cells) [28] \\
AQP9 & NM_020980 & aquaporin 9 & Up-regulation (liver) [29] \\
AS3MT & NM_020682 & arsenic (+3 oxidation state) methyltransferase & not available \\
SLC39A2 & NM_014579 & solute carrier family 39, member 2 & not available \\
\hline
\end{tabular}

as well as the association between gene expression and infant birth weight $(\mathrm{kg})$. The following covariates were evaluated for inclusion in our models: maternal age, maternal smoking status (never, former, current), maternal education level, infant birth weight, infant gender and gestational age. Covariates controlled in our models were those that associated with the exposure and the outcome of interest using a series of linear regression models. A power analysis indicated adequate statistical power for detecting low-moderate correlations (absolute correlation $(r)=0.24$; power $=80 \%$ ) at a significance level of 0.05 and the study sample size of 133 subjects (Additional file 1: Figure S2). The aforementioned analyses were carried out using the $\mathrm{R}$ statistical program, version 2.13 (http://cran.r-project.org/). A structural equation model was applied to estimate the direct and indirect paths for U-As, birth weight, and the expression of AQP9 and ENPP2 [31]. This analysis is an extension of multivariable regression analysis that permits the simultaneous modeling of multiple dependent variables, allowing variables to be modeled both as dependent and independent with respect to other variables. We use this methodology to investigate the indirect relationship between arsenic exposure and infant birth weight. M-plus 6.12 software was used to estimate the coefficient estimates describing the associations along paths and their corresponding bias-corrected $95 \%$ bootstrap (10,000 replicates) confidence intervals.

\section{Results}

The study group consists of 133 pregnant women enrolled in the New Hampshire pregnancy cohort (see Table 2 for demographic information). The mean infant birth weight was $3.4 \mathrm{~kg}$ (standard deviation (SD): $0.4 \mathrm{~kg}$ ), similar to the national average [32]. The median arsenic concentration in household tap water was $0.36 \mu \mathrm{g} / \mathrm{L}$ (interquartile range (IQR) 0.02 - 3.55) with $84 \%$ of the participants having drinking water containing arsenic levels less than the current drinking water MCL of $10 \mu \mathrm{g} / \mathrm{L}$. Total urinary arsenic concentration (U-As), incorporating both inorganic and organic metabolites (but not arsenobetaine), was also
Table 2 Demographic information of the study group

\begin{tabular}{|c|c|}
\hline Characteristic & Value $^{a}$ \\
\hline Number of mother-child pairs & 133 \\
\hline Mean gestational age (wks) & $39.5(1.6)$ \\
\hline Mean maternal age at delivery (yrs) & $31.1(4.6)$ \\
\hline Mean parity & $1.1(1.1)$ \\
\hline Mean pre-pregnancy BMI (kg/m2) & $24.9(4.7)$ \\
\hline Median tap water arsenic (/g/L) & $0.36\{0.02-3.55\}$ \\
\hline Median U-As (/g/L) & $4.4\{1.8-11.9\}$ \\
\hline \multicolumn{2}{|l|}{ School Level } \\
\hline Less than 11th grade & $3[2.6]$ \\
\hline High school graduate or equivalent & $10[7.5]$ \\
\hline Junior college graduate or some college & $28[21.1]$ \\
\hline \multicolumn{2}{|l|}{ or technical school } \\
\hline College graduate & $55[41.4]$ \\
\hline Post-graduate schooling & 18 [13.5] \\
\hline Unknown & 19 [14.3] \\
\hline \multicolumn{2}{|l|}{ Smoking status } \\
\hline Never & $97[72.9]$ \\
\hline Former & $13[9.8]$ \\
\hline Current & $5[3.8]$ \\
\hline Unknown & 18 [13.5] \\
\hline Mean infant birth weight (kg) & $3.4(0.4)$ \\
\hline \multicolumn{2}{|l|}{ Infant gender } \\
\hline Male & 65 [48.9] \\
\hline Female & $68[51.1]$ \\
\hline \multicolumn{2}{|l|}{ Infant race } \\
\hline White & 128 [96.2] \\
\hline Unknown & $5[3.8]$ \\
\hline
\end{tabular}

Values are presented as mean (SD), number [\%], or median \{interquartile range\}. 
measured among the participants. The median concentration of U-As was $4.4 \mu \mathrm{g} / \mathrm{L}$ (IQR 1.8 - 11.9), which was consistent with an exposure range previously observed for a nationally representative US sample [33].

We used fetal portions of the placenta as a source of tissue for examining gene expression because of its fetal origin, its critical role in fetal development and control of the intrauterine environment, and easy accessibility after parturition. Maternal U-As was used as the parameter for fetal arsenic exposure, as arsenic has been shown to easily cross the placental barrier [34,35]. Thus, maternal U-As levels likely reflect the burden experienced by the fetus. To identify arsenic-associated biomarkers, we examined the expression of a set of previously reported arsenicregulated genes (Table 1). Besides these putative arsenic target genes, the arsenic methyltransferase $(A S 3 M T)$ and the zinc transporter (SLC39A2) were included because these genes were linked to arsenic-related health outcomes in previous studies [36-38].

After consolidating the candidate gene list, we first examined the relationship between the placental expression of these genes and in utero arsenic exposure. Multivariable linear regression models were used to investigate the association between the normalized expression value of each gene, quantitated using the Nanostring system [23], with maternal U-As. Among all the genes examined, the expression of $A Q P 9$ was positively associated with arsenic exposure (coefficient estimate: 0.25; 95\% CI: $0.05-0.45$ ) (Figure 1A, Additional file 1: Figure S1 and Additional file 1: Table S1). Similar results were obtained when U-As was further adjusted for creatinine levels in samples where such data were available (Additional file 1: Table S2). We also evaluated whether other metal co-contaminants were related to both arsenic and $A Q P 9$ and could be potential confounders in our analysis. While toenail Manganese $(\mathrm{Mn})$ concentration showed the most significant association with arsenic levels from 88 participants in whom such data were available (Additional file 1: Table S3), the association between arsenic exposure and $A Q P 9$ expression was not affected by adjustment of Mn concentrations (Additional file 1: Table S4).

As $A Q P 9$ expression has been shown to enhance arsenic's effect on cultured cells $[39,40]$, presumably through increased arsenic uptake, we further determined the association between the expression of $A Q P 9$ and the other members of our panel of putative arsenic biomarkers. Such analysis revealed significant associations between $A Q P 9$ expression and five of the six arsenic-regulated
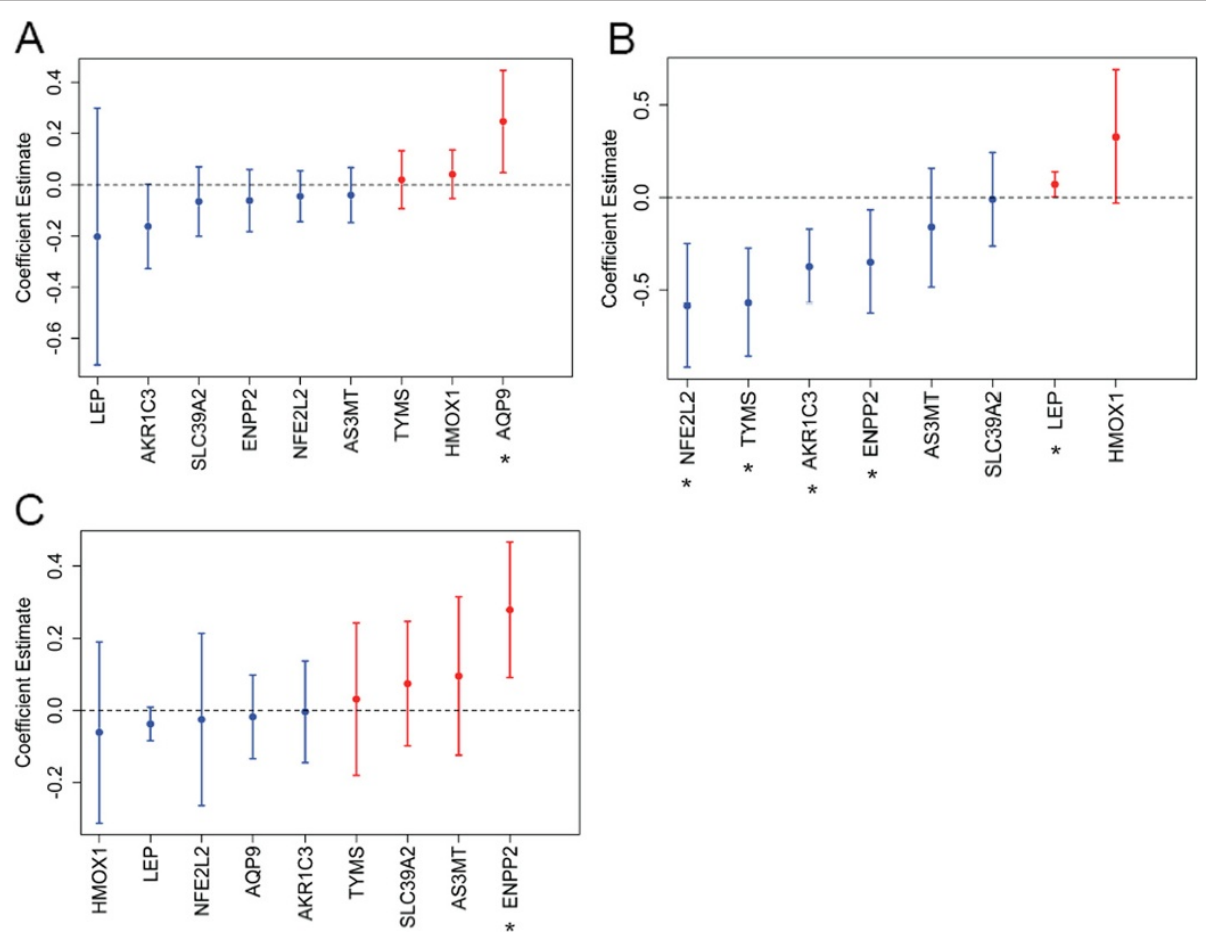

Figure 1 Associations between gene expression, maternal U-As, and birth weight. Multiple linear regression analyses for the association between (A) maternal U-As and placental gene expression, (B) AQP9 expression and the expression of other genes, and (C) infant birth weight and gene expression. All analyses were adjusted for maternal age. The analysis for birth weight and gene expression was further adjusted for gestational age. Dots depict coefficient estimates and error bars represent 95\% Cls. Positive coefficient estimates are marked in red and negative coefficient estimates are marked in blue. Significant associations are those with 95\% Cls not crossing zero (dotted line) and are marked by asterisks. 
genes in our panel (AKR1C3, ENPP2, LEP, NFE2L2, and $T Y M S$ ), but not with the two genes not regulated by arsenic (AS3MT and SLC39A2) (Figure 1B and Additional file 1: Table S5). Further, as mentioned, in utero arsenic exposure has been linked to several adverse birth conditions such as low birth weight. To explore the mechanism by which arsenic exposure might influence birth weight, we examined the association between expression of our panel of candidate placental genes and infant birth weight. Multivariable linear regression analysis indicated that the expression of the phospholipase ENPP2 was positively associated with increased infant birth weight (coefficient estimate: 0.28; 95\% CI: $0.09-0.47$ ) (Figure $1 \mathrm{C}$ and Additional file 1: Table S6). According to our analysis, a $10 \%$ increase in ENPP2 expression was associated with $27 \mathrm{~g}$ increase in infant birth weight. Although not a primary aim of this study, we also observed an inverse association between U-As and infant birth weight in our cohort (coefficient estimate: -1.30, adjusted for infant gender, maternal age, and gestational age). The scale of arsenic effect on birth weight in our study group, $-1.30 \mathrm{~g}$ per $1 \mu \mathrm{g} / \mathrm{L}$ increase in maternal U-As, was similar to those of previous studies $[11,12]$.

We further built a structural equation model to estimate how $A Q P 9$ and ENPP2 expression might contribute to arsenic-related affects on birth weight. Structural equation models have been successfully used for testing and estimating causal pathways and have been successfully employed for understanding the path from exposures to health outcomes [31,41-43]. For our study, this model incorporated the significant associations identified in this study to build a path from arsenic exposure to lower birth weight (Figure 2). According to this model, in utero arsenic exposure resulted in increased expression of $A Q P 9$, followed by decreased expression of ENPP2. Reduction in ENPP2 levels ultimately associated with decreased infant birth weight. The indirect path from arsenic exposure to lower birth weight, through expression of $A Q P 9$ and ENPP2 expression, was statistically significant (coefficient estimate: -0.009 ; $95 \%$ CI: $-0.032--0.001 ; 10,000$ replications for bootstrapping), suggesting that exposure to arsenic in utero may be related to lower birth weight through this path.

\section{Discussion}

From animal model experiments and epidemiologic studies from highly exposed populations, arsenic exposure has been associated with numerous adverse birth outcomes, such as low birth weight. However, the mechanisms by which arsenic induces these effects remain uncertain. Using placenta as the source of fetal tissue from a US cohort exposed to arsenic around the MCL, we identified the arsenic transporter AQP9 as a possible biomarker of arsenic exposure in fetal tissues. We subsequently identified a positive association between ENPP2 expression and infant birth weight. We further developed a statistical path model whereby arsenic exposure related to lower infant birth weight through the modulation of $A Q P 9$ and ENPP2 expression. Thus, our model offers some insight into a possible mechanism underlying the inverse association between maternal arsenic exposure and infant birth weight.

AQP9 is an arsenic transporter $[44,45]$. Therefore, its increased expression has the potential to modulate the effect of arsenic on target cells. Consistent with this hypothesis, $A Q P 9$ expression levels have been shown to modulate the effect of arsenic on cultured cells including those derived from human placenta $[39,40]$. Arsenic exposure, and resultant increased $A Q P 9$ induced cytotoxicity of placental cells in theory could impact the function of the placenta, and thereby influence fetal growth and development. We speculated that increased placental $A Q P 9$ expression also might enhance arsenic's effect on fetal tissues. Indeed, $A Q P 9$ expression was significantly associated with five of the six arsenic-regulated genes in our panel (Figure 1B and Additional file 1: Table S5). Interestingly, AQP9 expression was negatively associated with the expression of ENPP2, AKR1C3 and NFE2L2, in contrast to the increased expression previously reported in response to arsenic exposure in cultured mammalian cells (Table 1). U-As itself was inversely related to the expression of these same genes in our study cohort (Figure 1A, Additional file 1: Table S1 and Table S2). Thus, the inverse association between $A Q P 9$ expression and ENPP2, AKR1C3, and NFE2L2

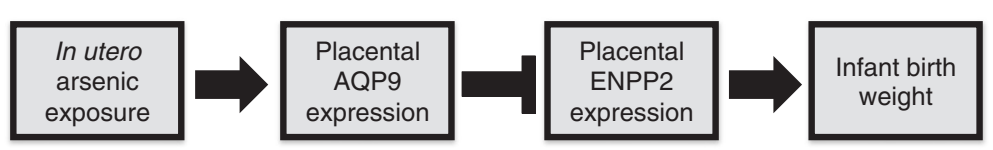

Figure 2 Structural equation model for the effect of arsenic on birth weight. The diagram illustrates the estimated path from arsenic exposure to birth weight. Variables are represented by rectangles. Each path is represented by a line with an arrow or vertical bar at one end. Arrow denotes positive association and vertical bar denotes negative association. The calculated coefficient estimate and $95 \% \mathrm{Cl}$ for each path are: in utero arsenic exposure (U-As) and placental AQP9 expression (coefficient estimate: 0.25; 95\% Cl: 0.05 - 0.45); placental AQP9 expression and ENPP2 expression (coefficient estimate: -0.13; 95\% Cl: -0.22 - -0.02); placental ENPP2 expression and infant birth weight (coefficient estimate: 0.28; $95 \% \mathrm{Cl}: 0.09-0.47)$. The indirect path from $\mathrm{U}$-As to infant birth weight has a coefficient estimate of -0.009 and a $95 \% \mathrm{Cl}$ of -0.032 to -0.001 ( $\mathrm{n}=$ 133 and 10000 replications for bootstrapping). 
expression could reflect a unique regulation by arsenic on these genes in human placenta. Besides arsenic, AQP9 transports solutes such as urea, glycerol, and monocarboxylates [46]. Thus, it remains possible that the observed associations between the expression of $A Q P 9$ and some of the arsenic-related gene expression biomarkers may be indirect.

We hypothesize that arsenic exposure leads to lower birth weight by regulating the expression of $A Q P 9$ and ENPP2 based on the results of our structure equation model. Although direct evidence supporting this model is lacking, $A Q P 9$ and ENPP2 are expressed during human pregnancy under both physiologic and pathological conditions. For example, $A Q P 9$ expression was elevated in placentas obtained from preeclamptic mothers [47]. ENPP2 encodes a secreted phospholipase that catalyzes the conversion of lysophosphatidylcholine to lysophosphatidic acid (LPA) [48]. During pregnancy, the expression level of ENPP2 in trophoblasts rises, contributing to the high circulating levels of ENPP2 and LPA in the serum of pregnant women $[49,50]$. LPA activates its cell surface receptors to regulate various processes relevant to reproduction, from angiogenesis and early embryonic development to embryo implantation and parturition, hence conceivably impacting birth weight [51]. Indeed, mice overexpressing lipid phosphate phosphatase 1 (LPP1), an enzyme that dephosphophorylates LPA, are born with lower birth weight [52]. Additionally, decreased levels of serum ENPP2 is associated with pregnancy-induced hypertension [53], which itself is associated with decreased infant birth weight [54]. While our findings suggest that placental expression of $A Q P 9$ and ENPP2 is related to in utero arsenic exposure and infant birth weight respectively, future research is necessary to validate these biomarkers in independent cohorts and to determine the precise molecular mechanisms of how arsenic exposure impacts birth weight through AQP9 and ENPP2.

\section{Conclusions}

We have identified the expression of $A Q P 9$ and ENPP2 as novel potential fetal biomarkers, relating arsenic exposure to infant birth weight. As our results were based on a cohort of pregnant women exposed to arsenic levels above and below its MCL, these findings are relevant to pregnant women exposed to such levels of arsenic throughout the world.

\section{Additional file}

Additional file 1: Table S1. Associations between maternal urinary arsenic concentrations during pregnancy (U-As) and the expression of placental genes. Table S2. Associations between maternal urinary arsenic concentrations during pregnancy (U-As) and the expression of placental genes after further adjustment of urinary creatinine levels in a subset of participants $(n=91)$. Table S3. The association between maternal toenail arsenic and other metals in a subset of participants $(n=88)$. Table S4. The association between maternal urinary arsenic concentrations during pregnancy (U-As) and AQP9 expression with or without adjustment of toenail Mn levels in a subset of participants $(n=88)$. Table S5. Associations between the placental expression of AQP9 and that of other genes. Table S6. Associations between placental gene expression and infant birth weight. Figure S1. Scattered plot view of the association between U-As and the placental expression of AQP9. Figure S2. Sample size power analysis.

\section{Abbreviations}

Cl: Confidence interval; IQR: Interquartile range; MCL: Maximum contaminant level; U-As: Total urinary arsenic concentration.

\section{Competing interests}

The authors declare no competing interests.

\section{Authors' contributions}

DLF, JAG, MRK, and DJR designed research; DLF and CG performed research; DLF, DCK, AS, ZL, CJM, and MRK analyzed data; DLF, DCK, MRK, and DJR wrote the paper. All authors read and approved the final manuscript.

\section{Acknowledgements}

We thank the members of the Robbins' and Karagas' laboratories, M. Huyck, J. Gruber, A. Capobianco and E. Dmitrovsky for helpful discussions during the course of this work. This work was supported by NIEHS P20 grant ES018175 (DJR \& MRK) and P42 ES007373 (MRK), EPA P20 grant RD83459901 (DJR \& MRK), and GM64011 (DJR). This manuscript is the result of equal contributions from both the Karagas and Robbins laboratories.

\section{Author details}

${ }^{1}$ Department of Surgery, Molecular Oncology Program, Miller School of Medicine, University of Miami, Miami, FL 33136, USA. ²Department of Pharmacology and Toxicology, Program in Experimental and Molecular Medicine, Geisel School of Medicine at Dartmouth, Hanover, NH 03755, USA. ${ }^{3}$ Department of Community and Family Medicine, Geisel School of Medicine at Dartmouth, Hanover, NH 03755, USA. ${ }^{4}$ Department of Molecular and Biomedical Sciences, University of Maine, Orono, ME 04469, USA. ${ }^{5}$ Department of Biochemistry and Molecular Biology, Miller School of Medicine, University of Miami, Miami, FL 33136, USA. 'Department of Surgery, Molecular Oncology Program, Department of Biochemistry and Molecular Biology, Sylvester Comprehensive Cancer Center, Miller School of Medicine, University of Miami, Miami, FL 33136, USA. ${ }^{7}$ Current address: National Institutes of Health, National Human Genome Research Institute, Bethesda, MD 20892, USA.

Received: 15 April 2013 Accepted: 1 July 2013

Published: 16 July 2013

\section{References}

1. NRC: Arsenic in Drinking Water. Washington, DC: National Academy Press; 1999.

2. IARC: Some drinking-water disinfectants and contaminants, including arsenic. In IARC monographs on the evaluation of carcinogenic risks to humans. vol. 84. France: IARC Press; 2004:37-270.

3. Vahter M: Effects of arsenic on maternal and fetal health. Annu Rev Nutr 2009, 29:381-399.

4. Ahmad SA, Sayed MH, Barua S, Khan MH, Faruquee MH, Jalil A, Hadi SA, Talukder HK: Arsenic in drinking water and pregnancy outcomes. Environ Health Perspect 2001, 109:629-631.

5. Rahman A, Vahter M, Ekstrom EC, Rahman M, Golam Mustafa AH, Wahed MA, Yunus M, Persson LA: Association of arsenic exposure during pregnancy with fetal loss and infant death: a cohort study in Bangladesh. Am J Epidemiol 2007, 165:1389-1396.

6. Milton AH, Smith W, Rahman B, Hasan Z, Kulsum U, Dear K, Rakibuddin M, Ali A: Chronic arsenic exposure and adverse pregnancy outcomes in bangladesh. Epidemiology 2005, 16:82-86. 
7. Kwok RK, Kaufmann RB, Jakariya M: Arsenic in drinking-water and reproductive health outcomes: a study of participants in the Bangladesh Integrated Nutrition Programme. J Health Popul Nutr 2006, 24:190-205.

8. Huyck KL, Kile ML, Mahiuddin G, Quamruzzaman Q, Rahman M, Breton CV, Dobson CB, Frelich J, Hoffman E, Yousuf J, Afroz S, Islam S, Christiani DC: Maternal arsenic exposure associated with low birth weight in Bangladesh. Journal of occupational and environmental medicine/American College of Occupational and Environmental Medicine 2007, 49:1097-1104.

9. Hood RD, Bishop SL: Teratogenic effects of sodium arsenate in mice. Arch Environ Health 1972, 24:62-65.

10. Ferm VH, Carpenter SJ: Malformations induced by sodium arsenate. J Reprod Fertil 1968, 17:199-201.

11. Rahman A, Vahter M, Smith AH, Nermell B, Yunus M, El Arifeen S, Persson L-A, Ekström E-C: Arsenic exposure during pregnancy and size at birth: a prospective cohort study in Bangladesh. Am J Epidemiol 2009, 169:304-312.

12. Hopenhayn C, Ferreccio C, Browning SR, Huang B, Peralta C, Gibb H, HertzPicciotto I: Arsenic exposure from drinking water and birth weight. Epidemiology (Cambridge, Mass) 2003, 14:593-602.

13. Fry RC, Navasumrit $P$, Valiathan $C$, Svensson JP, Hogan BJ, Luo M, Bhattacharya S, Kandjanapa K, Soontararuks S, Nookabkaew S, Mahidol C, Ruchirawat M, Samson LD: Activation of inflammation/NF-kappaB signaling in infants born to arsenic-exposed mothers. PLOS Genet 2007, 3:e207.

14. Ahmed S, Mahabbat-e Khoda S, Rekha RS, Gardner RM, Ameer SS, Moore S, Ekstrom EC, Vahter M, Raqib R: Arsenic-associated oxidative stress, inflammation, and immune disruption in human placenta and cord blood. Environ Health Perspect 2011, 119:258-264.

15. Marsit CJ, Maccani MA, Padbury JF, Lester BM: Placental 11-beta hydroxysteroid dehydrogenase methylation is associated with newborn growth and a measure of neurobehavioral outcome. PLOS One 2012, 7:e33794.

16. Wilhelm-Benartzi CS, Houseman EA, Maccani MA, Poage GM, Koestler DC, Langevin SM, Gagne LA, Banister CE, Padbury JF, Marsit CJ: In utero exposures, infant growth, and DNA methylation of repetitive elements and developmentally related genes in human placenta. Environ Heal Perspect 2012, 120:296-302.

17. Gilbert-Diamond D, Cottingham KL, Gruber JF, Punshon T, Sayarath V, Gandolfi AJ, Baker ER, Jackson BP, Folt CL, Karagas MR: Rice consumption contributes to arsenic exposure in US women. Proc Natl Acad Sci U S A 2011, 108:20656-20660.

18. Jackson BP, Taylor VF, Karagas MR, Punshon T, Cottingham KL: Arsenic, organic foods, and brown rice syrup. Environ Health Perspect 2012 120:623-626.

19. Meharg AA, Sun G, Williams PN, Adomako E, Deacon C, Zhu YG, Feldmann J, Raab A: Inorganic arsenic levels in baby rice are of concern. Environ Pollut 2008, 152:746-749

20. Carbonell-Barrachina AA, Wu X, Ramirez-Gandolfo A, Norton GJ, Burlo F, Deacon C, Meharg AA: Inorganic arsenic contents in rice-based infant foods from Spain, UK, China and USA. Environ Pollut 2012, 163:77-83.

21. Smolders R, Bartonova A, Boogaard PJ, Dusinska M, Koppen G, Merlo F, Sram RJ, Vineis P, Schoeters G: The use of biomarkers for risk assessment: Reporting from the INTARESE/ENVIRISK Workshop in Prague. Int J Hyg Environ Health 2010, 213:395-400.

22. Wild CP: Environmental exposure measurement in cancer epidemiology. Mutagenesis 2009, 24:117-125.

23. Geiss GK, Bumgarner RE, Birditt B, Dahl T, Dowidar N, Dunaway DL, Fell HP, Ferree S, George RD, Grogan T, James JJ, Maysuria M, Mitton JD, Oliveri P, Osborn JL, Peng T, Ratcliffe AL, Webster PJ, Davidson EH, Hood L, Dimitrov K: Direct multiplexed measurement of gene expression with color-coded probe pairs. Nat Biotechnol 2008, 26:317-325.

24. Chien CW, Ho IC, Lee TC: Induction of neoplastic transformation by ectopic expression of human aldo-keto reductase $1 \mathrm{C}$ isoforms in NIH3T3 cells. Carcinogenesis 2009, 30:1813-1820

25. Yu X, Robinson JF, Gribble E, Hong SW, Sidhu JS, Faustman EM: Gene expression profiling analysis reveals arsenic-induced cell cycle arrest and apoptosis in p53-proficient and p53-deficient cells through differential gene pathways. Toxicol Appl Pharmacol 2008, 233:389-403.

26. Fei DL, Li H, Kozul CD, Black KE, Singh S, Gosse JA, DiRenzo J, Martin KA, Wang B, Hamilton JW, Karagas MR, Robbins DJ: Activation of Hedgehog signaling by the environmental toxicant arsenic may contribute to the etiology of arsenic-induced tumors. Cancer Res 2010, 70:1981-1988.
27. Pi J, Qu W, Reece JM, Kumagai Y, Waalkes MP: Transcription factor Nrf2 activation by inorganic arsenic in cultured keratinocytes: involvement of hydrogen peroxide. Exp Cell Res 2003, 290:234-245.

28. Ardalan B, Subbarayan PR, Ramos Y, Gonzalez M, Fernandez A, Mezentsev D, Reis I, Duncan R, Podolsky L, Lee K, Lima M, Ganjei-Azar P: A phase I study of 5-fluorouracil/leucovorin and arsenic trioxide for patients with refractory/relapsed colorectal carcinoma. Clin Cancer Res 2010, 16:3019-3027.

29. Torres-Avila M, Leal-Galicia P, Sanchez-Pena LC, Del Razo LM, Gonsebatt ME: Arsenite induces aquaglyceroporin 9 expression in murine livers. Environ Res 2010, 110:443-447.

30. Johnson WE, Li C, Rabinovic A: Adjusting batch effects in microarray expression data using empirical Bayes methods. Biostatistics 2007, 8:118-127.

31. Kline RB: Principles and Practice of Structural Equation Modeling. 3rd edition. New York: Guilford Press; 2004.

32. David RJ, Collins JW: Differing birth weight among infants of U.S.-born blacks, African-born blacks, and U.S.-born whites. N Engl J Med 1997, 337:1209-1214.

33. Caldwell $\mathrm{KL}$, Jones RL, Verdon CP, Jarrett JM, Caudill SP, Osterloh JD: Levels of urinary total and speciated arsenic in the US population: National Health and Nutrition Examination Survey 2003-2004. J Expo Sci Environ Epidemio/ 2009, 19:59-68.

34. Concha G, Vogler G, Lezcano D, Nermell B, Vahter M: Exposure to inorganic arsenic metabolites during early human development. Toxicol Sci 1998, 44:185-190

35. Hall M, Gamble M, Slavkovich V, Liu X, Levy D, Cheng Z, van Geen A, Yunus M, Rahman M, Pilsner JR, Graziano J: Determinants of arsenic metabolism: blood arsenic metabolites, plasma folate, cobalamin, and homocysteine concentrations in maternal-newborn pairs. Environ Health Perspect 2007, 115:1503-1509.

36. Karagas MR, Andrew AS, Nelson HH, Li Z, Punshon T, Schned A, Marsit CJ, Morris JS, Moore JH, Tyler AL, Gilbert-Diamond D, Guerinot M-L, Kelsey KT: SLC39A2 and FSIP1 polymorphisms as potential modifiers of arsenicrelated bladder cancer. Hum Genet 2012, 131:453-461.

37. Gong G, O'Bryant SE: Low-level arsenic exposure, AS3MT gene polymorphism and cardiovascular diseases in rural Texas counties. Environ Res 2012, 113:52-57.

38. Drobná Z, Del Razo LM, García-Vargas GG, Sánchez-Peña LC, Barrera-Hern ández A, Stýblo M, Loomis D: Environmental exposure to arsenic, AS3MT polymorphism and prevalence of diabetes in Mexico. Journal of exposure science \&amp; environmental epidemiology 2012, 23:151-155.

39. Shinkai Y, Sumi D, Toyama T, Kaji T, Kumagai Y: Role of aquaporin 9 in cellular accumulation of arsenic and its cytotoxicity in primary mouse hepatocytes. Toxicol Appl Pharmacol 2009, 237:232-236.

40. Yoshino Y, Yuan B, Kaise T, Takeichi M, Tanaka S, Hirano T, Kroetz DL, Toyoda $\mathrm{H}$ : Contribution of aquaporin 9 and multidrug resistanceassociated protein 2 to differential sensitivity to arsenite between primary cultured chorion and amnion cells prepared from human fetal membranes. Toxicol Appl Pharmacol 2011, 257:198-208.

41. Antonogeorgos G, Panagiotakos DB, Pitsavos C, Papageorgiou C, Chrysohoou C, Papadimitriou GN, Stefanadis C: Understanding the role of depression and anxiety on cardiovascular disease risk, using structural equation modeling; the mediating effect of the Mediterranean diet and physical activity: the ATTICA study. Ann Epidemio/ 2012, 22:630-637.

42. Arlinghaus A, Lombardi DA, Willetts JL, Folkard S, Christiani DC: A structural equation modeling approach to fatigue-related risk factors for occupational injury. Am J Epidemiol 2012, 176:597-607.

43. Baja ES, Schwartz JD, Coull BA, Wellenuis GA, Vokonas PS, Suh HH: Structural equation modeling of the inflammatory response to traffic air pollution. J Expo Sci Environ Epidemiol 2012, 23:268-274.

44. Rosen BP: Biochemistry of arsenic detoxification. FEBS Lett 2002, 529:86-92.

45. Damiano AE: Review: Water channel proteins in the human placenta and fetal membranes. Placenta 2011, 32(Suppl 2):S207-211.

46. Tsukaguchi H, Shayakul C, Berger UV, Mackenzie B, Devidas S, Guggino WB, van Hoek AN, Hediger MA: Molecular characterization of a broad selectivity neutral solute channel. J Biol Chem 1998, 273:24737-24743.

47. Damiano $A E$, Zotta E, Ibarra C: Functional and molecular expression of AQP9 channel and UT-A transporter in normal and preeclamptic human placentas. Placenta 2006, 27:1073-1081. 
48. Okudaira S, Yukiura H, Aoki J: Biological roles of lysophosphatidic acid signaling through its production by autotaxin. Biochimie 2010, 92:698-706.

49. Iwasawa Y, Fujii T, Nagamatsu T, Kawana K, Okudaira S, Miura S, Matsumoto J, Tomio A, Hyodo H, Yamashita T, Oda K, Kozuma S, Aoki J, Yatomi Y, Taketani Y: Expression of autotaxin, an ectoenzyme that produces lysophosphatidic acid, in human placenta. Am J Reprod Immunol 2009, 62:90-95.

50. Tokumura A, Kanaya Y, Miyake M, Yamano S, Irahara M, Fukuzawa K: Increased production of bioactive lysophosphatidic acid by serum lysophospholipase D in human pregnancy. Biol Reprod 2002, 67:1386-1392.

51. Ye X: Lysophospholipid signaling in the function and pathology of the reproductive system. Hum Reprod Update 2008, 14:519-536.

52. Yue J, Yokoyama K, Balazs L, Baker DL, Smalley D, Pilquil C, Brindley DN, Tigyi G: Mice with transgenic overexpression of lipid phosphate phosphatase-1 display multiple organotypic deficits without alteration in circulating lysophosphatidate level. Cell Signal 2004, 16:385-399.

53. Masuda A, Fujii T, Iwasawa Y, Nakamura K, Ohkawa R, Igarashi K, Okudaira S, Ikeda H, Kozuma S, Aoki J, Yatomi Y: Serum autotaxin measurements in pregnant women: application for the differentiation of normal pregnancy and pregnancy-induced hypertension. Clin Chim Acta 2011, 412:1944-1950.

54. Rahman LA, Hairi NN, Salleh N: Association between pregnancy induced hypertension and low birth weight; a population based case-control study. Asia Pac J Public Health 2008, 20:152-158.

doi:10.1186/1476-069X-12-58

Cite this article as: Fei et al:: Association between In Utero arsenic exposure, placental gene expression, and infant birth weight: a US birth cohort study. Environmental Health 2013 12:58.

\section{Submit your next manuscript to BioMed Central and take full advantage of:}

- Convenient online submission

- Thorough peer review

- No space constraints or color figure charges

- Immediate publication on acceptance

- Inclusion in PubMed, CAS, Scopus and Google Scholar

- Research which is freely available for redistribution 